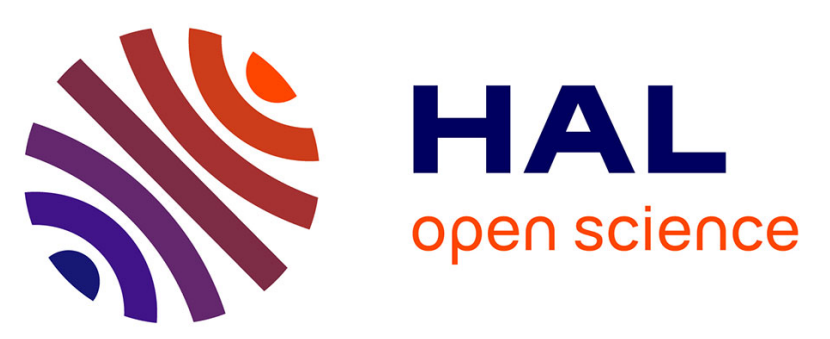

\title{
Evidence of coordinative chain transfer polymerization of isoprene using iron iminopyridine/ZnEt2 catalytic systems
}

\author{
Obaid H Hashmi, Marc Visseaux, Yohan Champouret
}

\section{To cite this version:}

Obaid H Hashmi, Marc Visseaux, Yohan Champouret. Evidence of coordinative chain transfer polymerization of isoprene using iron iminopyridine/ZnEt2 catalytic systems. Polymer Chemistry, 2021, 12, pp.4626 - 4631. 10.1039/d1py00433f . hal-03334073

\section{HAL Id: hal-03334073 \\ https://hal.science/hal-03334073}

Submitted on 3 Sep 2021

HAL is a multi-disciplinary open access archive for the deposit and dissemination of scientific research documents, whether they are published or not. The documents may come from teaching and research institutions in France or abroad, or from public or private research centers.
L'archive ouverte pluridisciplinaire HAL, est destinée au dépôt et à la diffusion de documents scientifiques de niveau recherche, publiés ou non, émanant des établissements d'enseignement et de recherche français ou étrangers, des laboratoires publics ou privés. 


\title{
Evidence of Coordinative Chain Transfer Polymerization of Isoprene using Iron Iminopyridine/ZnEt ${ }_{2}$ Catalytic Systems
}

\author{
Obaid H. Hashmi, ${ }^{a}$ Marc Visseaux ${ }^{\mathrm{a}, *}$ and Yohan Champouret ${ }^{\mathrm{a}, *}$ \\ a. Univ. Lille, CNRS, Centrale Lille, Univ. Artois, UMR 8181 - UCCS - Unité de Catalyse et de Chimie du Solide, F-59000 Lille, France. E- \\ mail:marc.visseaux@univ-lille.fr, yohan.champouret@univ-lille.fr \\ + Electronic Supplementary Information (ESI) available: Experimental part and characterization data. See DOI: 10.1039/d1py00433f
}

\begin{abstract}
Isoprene polymerization using iminopyridine-supported iron complexes combined with $\mathrm{Al}^{i} \mathrm{Bu} u_{3} /\left[\mathrm{B}\left(\mathrm{C}_{6} \mathrm{~F}_{5}\right)_{4}\right]\left[\mathrm{CPh}_{3}\right]$ was carried out in the presence of $\mathrm{ZnEt}_{2}$ as chain transfer agent (CTA). Detailed studies revealed that the $M_{n}$ of the resulting polyisoprenes and the rate of polymerization decrease steadily as the amount of CTA increases while preserving the catalyst selectivity. These results highlight the first example of a reversible iron-mediated chain transfer polymerization of isoprene.
\end{abstract}

To date, coordinative chain transfer polymerization (CCTP) processes are predominantly based on olefin monomers and it is only recently that this methodology has been extended to conjugated dienes. ${ }^{1}$ For the latter ones, the few examples disclosed in the literature have exclusively focused on rare earth metal-based systems ${ }^{2}$ combined with $\mathrm{Al}$ or Mg as Chain Transfer Agent (CTA). To our knowledge, the implementation of transition metal-catalyzed CCTP of conjugated dienes remains to be proven, especially for iron complexes. ${ }^{2 b, 3-5}$ In this paper, we describe the first successful CCTP of isoprene using iminopyridine iron complexes in the presence of $\mathrm{ZnEt}_{2}$ as CTA, after proper cocatalyst activation.

In the quest of sustainable chemistry, iron catalysis is currently witnessing a major revival given the natural abundance and relative non-toxicity of this metal, which offers a suitable substitute to other metal-based systems involved in the catalytic transformation of organic substrates. ${ }^{6}$ Notably, the development of well-defined single-site iron-based complexes has led to an increased attention in coordination-insertion polymerization of polar and nonpolar monomers, ${ }^{7}$ with a more focus over the last few decades on the polymerization of ethylene. ${ }^{8} \mathrm{~A}$ significant breakthrough in this field was described by Gibson and coworkers who carried out a polymerization of ethylene using the bis(imino)pyridine iron dichloride/methylaluminoxane catalytic system $\left[(\mathrm{BIP}) \mathrm{FeCl}_{2} / \mathrm{MAO},[\mathrm{BIP}=\right.$ bis(imino)pyridine, $\mathrm{MAO}=$ methylaluminoxane $]$ in the presence of a large amount of $\mathrm{ZnEt}_{2}$, which allowed accurate control of the macromolecular data $\left(M_{n}, \oslash\right)$ of the resulting polymer. ${ }^{9}$ In this process, known as CCTP, the growing polymer chain is reversibly transferred-from the active Fe center to the dormant CTA Zn center via a

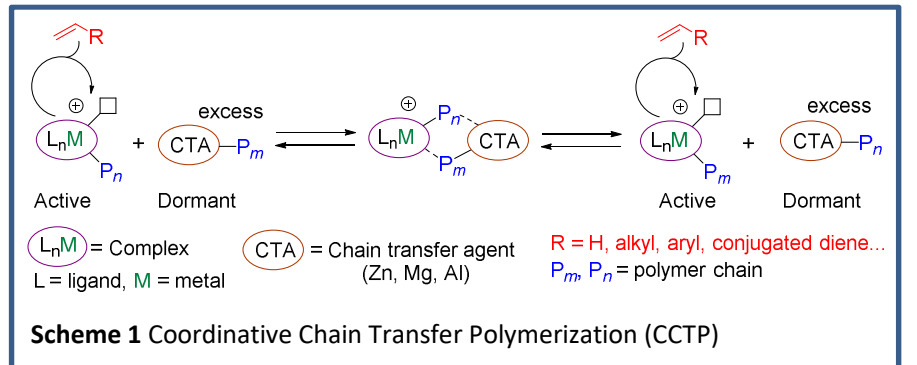
putative heterobimetallic Fe/Zn intermediate (Scheme 1). ${ }^{1}$ This methodology exhibits living characteristics and enables the control growth of several macromolecular chains per catalyst molecule since $i$ ) the chain transfer is fully reversible, ii) its rate is fast compared to the rate of propagation, iii) the formation of the heterobimetallic intermediate has a sufficient lifetime for the CCTP to be effective and $i v$ ) the chain transfer occurs in absence of any undesired irreversible transfer/termination pathway. ${ }^{1}$ All these requirements are highly dependent on the electronic and steric properties of the catalyst, besides the nature and adequacy of the CTA with the monomer used. As a result, narrow dispersities are obtained with the macromolecular chains terminated by the chain transfer agent, which enables further polymer chain-end functionalization, the preparation of block copolymers and, subsequently, the elaboration by chain shuttling polymerization (CSP) of copolymers featuring multi-block architecture.

Up to now, coordinative polymerization of conjugated dienes, such as butadiene, isoprene and derivatives, remains a preferred choice to obtain effectively polydiene materials with desired molar masses along with controlled microstructures. ${ }^{10}$ In the case of polyisoprene, the resulting polymer can present different arrangements comprising cis-1,4, trans-1,4, 3,4- and, occasionally, 1,2-vinyl sequences or a combination of these units that dictates the enduse applications of the material in the rubber industry. ${ }^{11}$ Within this framework, we ${ }^{12}$ and others, ${ }^{13}$ have recently described that discrete iron-based complexes bearing an iminopyridine ligand are capable of efficiently catalyze the coordinative polymerization of isoprene after activation by an appropriate cocatalyst, some of them exhibiting high control of stereoselectivity. 
In the present work, we focused our study on the implementation of CCTP of isoprene. For this purpose, we have targeted on the use of $\mathrm{ZnEt}_{2}$ as CTA, since previous studies have shown that this CTA associates successfully with the (BIP) $\mathrm{FeCl}_{2} / \mathrm{MAO}$ catalyst system for the CCTP of ethylene ${ }^{9,14}$ and acetylene. ${ }^{15}$

The CCTP of isoprene was initially carried out using the Fe-based complexes 1-4 (Scheme 2) combined with $\mathrm{Al}^{\mathrm{B}} \mathrm{Bu}_{3} /\left[\mathrm{B}\left(\mathrm{C}_{6} \mathrm{~F}_{5}\right)_{4}\right]\left[\mathrm{CPh}_{3}\right]$ (isoprene/Fe/Ali $\mathrm{Bu}_{3} /\left[\mathrm{Ph}_{3} \mathrm{C}\right]\left[\mathrm{B}\left(\mathrm{C}_{6} \mathrm{~F}_{5}\right)_{4}\right.$

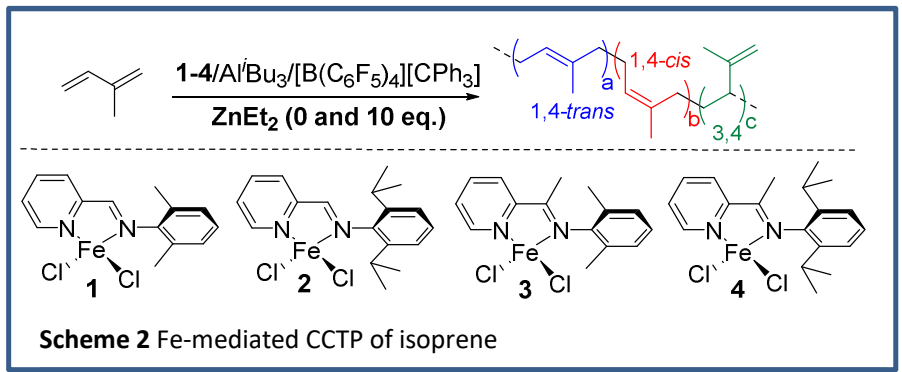
$2000 / 1 / 3 / 1)$ under optimized conditions, ${ }^{12}$ in the absence and the presence of $\mathrm{ZnEt}_{2}(\mathrm{Zn} / \mathrm{Fe}$ =10), the results are gathered in Table 1 (see also Figs. S1-S10 for SEC traces, ESIt). As previously reported, ${ }^{12}$ activation of complexes 1 to 3 with $\mathrm{Al}^{\prime} \mathrm{Bu}_{3} /\left[\mathrm{B}\left(\mathrm{C}_{6} \mathrm{~F}_{5}\right)_{4}\right]\left[\mathrm{CPh}_{3}\right]$, without $\mathrm{ZnEt}_{2}$, produced polyisoprenes with $M_{\mathrm{n}}$ values higher than the theoretical ones, which speaks in favor of a much higher propagation rate with respect to the initiation steps, while the $4 / \mathrm{Al}^{i} \mathrm{Bu} u_{3} /\left[\mathrm{B}\left(\mathrm{C}_{6} \mathrm{~F}_{5}\right)_{4}\right]\left[\mathrm{CPh}_{3}\right]$ catalytic system yielded polymers with $M_{\mathrm{n}}$ experimental close to the theoretical value (vide infra). The expected CCTP effects of the CTA upon the polymerization are $i$ ) decreasing $M_{n}$ values and ii) narrowing the dispersity ( $\theta$ value tending to 1 ). From the comparison of the results of the experiments performed with and without $\mathrm{ZnEt}_{2}$, the first criteria is fulfilled by precatalysts 1 to 4 , as for a complete conversion of isoprene, the $M_{\mathrm{n}}$ are reduced by a factor of 2.7 (complex $\mathbf{1}$, entries 1 vs 2), 1.3 (complex 2, entries 3 vs 4), 3 (complex 3, entries 5 vs 6) and 7.6 (complex 4, entries 7 vs 8), respectively. Although, the dispersity was found to increase slightly in the presence of 10 eq. of $\mathrm{ZnEt}_{2}$ for complexes 1 and $\mathbf{2}(\Theta=1.6$ vs 1.7 and 1.3 vs 1.8 , respectively) while they remained constant for complexes 3 and $4(\theta=1.3)$.

\begin{tabular}{|c|c|c|c|c|c|c|c|c|c|}
\hline \multirow{2}{*}{ Entry $^{a}$} & \multirow{2}{*}{ Complex } & \multirow{2}{*}[\mathrm{Zn}]{$/[\mathrm{Fe}]$} & \multirow{2}{*}{$\begin{array}{l}\text { Time } \\
\text { (min) }\end{array}$} & \multirow{2}{*}{$\begin{array}{l}\text { Conv. } \\
(\%)\end{array}$} & \multirow{2}{*}{$\begin{array}{l}M_{\mathrm{n}(\exp )^{\mathrm{b}}} \\
(\mathrm{g} / \mathrm{mol})\end{array}$} & \multirow{2}{*}{$\oplus^{\mathrm{b}}$} & \multirow{2}{*}{$N$ chains ${ }^{b}$} & \multicolumn{2}{|c|}{ Microstructure ${ }^{c}(\%)$} \\
\hline & & & & & & & & 1,4 (trans/cis) & 3,4 \\
\hline 1 & \multirow{2}{*}{1} & 0 & 360 & $>99$ & 487500 & 1.6 & & $79(38 / 41)$ & 21 \\
\hline 2 & & 10 & 360 & $>99$ & 180000 & 1.7 & 2.7 & $79(33 / 46)$ & 21 \\
\hline 3 & \multirow{2}{*}{2} & 0 & 360 & $>99$ & 250000 & 1.3 & & $75(35 / 40)$ & 25 \\
\hline 4 & & 10 & 360 & $>99$ & 195000 & 1.8 & 1.3 & $75(32 / 43)$ & 25 \\
\hline 5 & \multirow{2}{*}{3} & 0 & 360 & $>99$ & 261000 & 1.3 & & $90(69 / 21)$ & 10 \\
\hline 6 & & 10 & 360 & $>99$ & 86000 & 1.3 & 3.0 & $91(69 / 22)$ & 9 \\
\hline 7 & \multirow{2}{*}{4} & 0 & 360 & $>99$ & 155000 & 1.3 & & $90(77 / 13)$ & 10 \\
\hline 8 & & 10 & 360 & $>99$ & 20500 & 1.3 & 7.6 & $91(79 / 12)$ & 9 \\
\hline $9^{d}$ & \multirow{3}{*}{4} & 0 & 360 & $>99$ & 41000 & 1.2 & & $92(76 / 16)$ & 8 \\
\hline $10^{d}$ & & $7 \mathrm{Al}^{\mathrm{i}} \mathrm{Bu}_{3}$ & 960 & $>99$ & 40000 & 1.6 & 1.0 & $92(78 / 14)$ & 8 \\
\hline $11^{d}$ & & 10 BuMgEt & 1080 & 0 & - & - & - & - & - \\
\hline
\end{tabular}

${ }^{a}$ Polymerization conditions: $10 \mu \mathrm{mol}$ of Fe(II) complex, isoprene/Fe/ $/ \mathrm{Al}^{i} \mathrm{Bu}_{3} /\left[\mathrm{Ph}_{3} \mathrm{C}\right]\left[\mathrm{B}\left(\mathrm{C}_{6} \mathrm{~F}_{5}\right)_{4}\right]=2000 / 1 / 3 / 1$, toluene $=20 \mathrm{~mL}$, $[\mathrm{C}]$ isoprene $=1 \mathrm{~mol} / \mathrm{L}$, temperature $=25^{\circ} \mathrm{C}$. ${ }^{b}$ Determined by size exclusion chromatography (SEC) analysis in THF using polystyrene standards, $\mathrm{N}$ chains $=M_{\mathrm{n}}(\mathrm{exp})$ without $\mathrm{CTA}_{\mathrm{A}} / \mathrm{M}_{\mathrm{n}(\exp ) \text { with CTA. }}{ }^{c}$ Determined by ${ }^{1} \mathrm{H}$ NMR and ${ }^{13} \mathrm{C}$ NMR. ${ }^{d}$ Isoprene/Fe/Ali $\mathrm{Bu}_{3} /\left[\mathrm{B}\left(\mathrm{C}_{6} \mathrm{~F}_{5}\right)_{4}\right]\left[\mathrm{CPh}_{3}\right]=500 / 1 / 3 / 1$.

Furthermore, the selectivity of each catalytic system was notably maintained during CCTP screening (Figs. S11-S20 for NMR spectra, ESI ${ }^{\dagger}$ ). For example, the high degree of selectivity of the $4 / \mathrm{Al}^{i} \mathrm{Bu} \mathrm{u}_{3} /\left[\mathrm{B}\left(\mathrm{C}_{6} \mathrm{~F}_{5}\right)_{4}\right]\left[\mathrm{CPh}_{3}\right]$ catalytic system produces polyisoprene, which microstructure, predominantly $1,4-$, is similar to that obtained in the presence of additional $\mathrm{ZnEt}_{2}$ (Table 1, entries 7 vs 8 ) and consists of approximately $77-79 \%$ of trans-1,4 units along with the contribution of 3,4 (ca. $9-10 \%)$ and cis-1,4 fractions (ca. $12-13 \%)$. This observation reveals that the growth of the polymer chain is probably not influenced by the presence of the CTA, suggesting distinct mechanistic elementary steps of insertion (Fe catalyst) and transfer (Fe/Zn heterobimetallic species). Among the four catalysts tested, the highest transfer efficiency was found for $4 / \mathrm{Al}^{i} \mathrm{Bu}_{3} /\left[\mathrm{B}\left(\mathrm{C}_{6} \mathrm{~F}_{5}\right)_{4}\right]\left[\mathrm{CPh}_{3}\right] / \mathrm{ZnEt}_{2}$ and may be attributed to a good bond strength adequacy, i.e. comparable bond strength value of the metal catalyst-growing polymer chain and of the metal CTA-dormant polymer chain, as previously observed for the catalyzed chain growth of ethylene and acetylene using [(BIP) $\left.\mathrm{FeCl}_{2}\right] / \mathrm{MAO}$ catalytic system in the presence of an excess of $\mathrm{ZnEt}_{2} \cdot{ }^{9}, 15 \mathrm{~A}$ similar hypothesis can be drawn in our case from the $4 / \mathrm{Al}^{i} \mathrm{Bu}_{3} /\left[\mathrm{B}\left(\mathrm{C}_{6} \mathrm{~F}_{5}\right)_{4}\right]\left[\mathrm{CPh}_{3}\right] / \mathrm{ZnEt}_{2}$ catalytic system with the assumption that metal-allyl bonds are involved in the polymerization of isoprene. ${ }^{16}$ Further attempts to assess CCTP of isoprene using 4 and 100 eq. of MAO in presence of various amounts of $\mathrm{ZnEt}_{2}$ resulted in a less efficient system (Table S1 and Figs. S21-S24, ESI+). Furthermore, Al and Mg alkyl compounds, uncommonly used as CTAs with Fe precatalysts, were screened in this frame with the most efficient complex 4. The use of an excess of $\mathrm{Al}^{i} \mathrm{Bu}_{3}$ with complex $4(\mathrm{Al} / \mathrm{Fe}=10 / 1)$ led to practically no change in the resulting polyisoprene $M_{\mathrm{n}}$ (entry 10 , Table $1, M_{\mathrm{n}}=40000 \mathrm{~g} / \mathrm{mol}$ ) compared to the $M_{\mathrm{n}}$ 
value obtained in the presence of 3 eq. of Al reagent (entry 9, Table $1, M_{n}=41000 \mathrm{~g} / \mathrm{mol}$ ). This result indicates that the transfer is not relevant between $\mathrm{Al}$ and Fe under our experimental conditions. Moreover, the broadening of the dispersity was noticeable (entries 9 vs 10 , Table $1, \emptyset=1.2$ vs 1.6); this observation was

also apparent when using $\mathrm{Al}^{\mathrm{B} B \mathrm{Bu}_{3}}$ in excess for rare earth catalytic

systems. ${ }^{17}$ The resulting polyisoprene was acquired in good yields (> 99\%), displaying similar microstructure as observed with 3 eq. of $\mathrm{Al}^{i} \mathrm{Bu}$. Furthermore, replacement of $\mathrm{Al}^{i} \mathrm{Bu}_{3}$ with a sterically less hindered aluminum CTA, $\mathrm{AlEt}_{3}$, did not significantly improve the transfer efficiency. ${ }^{18}$ In contrast, the 4-based system failed to produce polyisoprene (entry 11, Table 1) in presence of 10 eq. of butylethylmagnesium (BuMgEt, BEM), which is similar to that found in the case of ethylene polymerization using (BIP) $\mathrm{FeCl}_{2} / \mathrm{MAO} / \mathrm{Mg}^{n} \mathrm{Bu}_{2}(1 / 100 / 500) .{ }^{4 b}$ In addition to the question of the similarity of bond strengths between the catalyst-polymer chain and the CTA-polymer chain, it is clear that the monomeric nature of $\mathrm{ZnEt}_{2}$ as compared to aggregated $\mathrm{MgR}_{2}$ in non-polar solution ${ }^{19}$ could be an explanation for a better CCTP efficiency when associated with the most sterically hindered precatalyst 4 . The chain transfer between the catalyst originating from 4 associated with $\mathrm{ZnEt}_{2}$ was also examined through the kinetic profile of isoprene polymerization at $25^{\circ} \mathrm{C}$, without and with 10 eq. of $\mathrm{ZnEt}_{2}$ per Fe compound (Table S2, ESI + ). From the kinetic plots (Fig. S25a, ESI+), it is evident that the addition of 10 eq. $\mathrm{ZnEt}_{2}$ prolonged the polymerization time substantially, which nearly follows a first order kinetic profile with and without CTA (the process being even better controlled under polymer chain transfer regime, Fig. S25b, ESI + ), indicating minimal loss of active species during the polymerization. In addition, the plot of $M_{n}$ vs conversion (Fig. S25c, Figs S26-S35, ESI+) is consistent with a controlled polymerization process in absence and in the presence of CTA, as assessed by the linear relationship observed.

The 4/AliBu $/\left[\mathrm{B}\left(\mathrm{C}_{6} \mathrm{~F}_{5}\right)_{4}\right]\left[\mathrm{CPh}_{3}\right]$ catalytic system was further assessed by conducting a detailed study through the variation in the amount of $\mathrm{ZnEt}_{2}$ during the polymerization process. The quantity of $\mathrm{ZnEt}_{2}\left(0-100\right.$ eq. of $\left.\mathrm{ZnEt}_{2} \mathrm{vs}_{4}\right)$ was monitored and its impact on the molar masses of the resulting polyisoprenes was observed, the results of which are displayed in Table 2 and Fig. 1.

\begin{tabular}{|c|c|c|c|c|c|}
\hline Entry & {$\left[\mathrm{ZnEt}_{2}\right] /[4]$} & Conv. (\%) & $\begin{array}{l}M_{\mathrm{n}(\exp )^{b}} \\
(\mathrm{~g} / \mathrm{mol})\end{array}$ & $\oplus^{\mathrm{b}}$ & $N$ chains $^{c}$ \\
\hline 1 & 0 & $>99$ & 155000 & 1.3 & - \\
\hline 2 & 5 & $>99$ & 33000 & 1.5 & 4.7 \\
\hline 3 & 10 & $>99$ & 20500 & 1.3 & 7.6 \\
\hline 4 & 20 & $>99$ & 15000 & 1.2 & 10.3 \\
\hline 5 & 30 & $>99$ & 12000 & 1.3 & 13 \\
\hline 6 & 40 & $>99$ & 10000 & 1.3 & 15.5 \\
\hline 7 & 50 & $>99$ & 8000 & 1.3 & 19.4 \\
\hline 8 & 100 & 64 & 6600 & 1.2 & $15.0^{d}$ \\
\hline
\end{tabular}

${ }^{a}$ Polymerization conditions: $10 \mu \mathrm{mol}$ of $\mathrm{Fe}(\mathrm{II})$ complex, isoprene/Fe/ $/ \mathrm{Al}^{i} \mathrm{Bu}_{3} /\left[\mathrm{B}\left(\mathrm{C}_{6} \mathrm{~F}_{5}\right)_{4}\right]\left[\mathrm{CPh}_{3}\right]=2000 / 1 / 3 / 1$, toluene $=20 \mathrm{~mL}$, [C]isoprene $=1 \mathrm{~mol} / \mathrm{L}$, temperature $=25{ }^{\circ} \mathrm{C}$, time $=6 \mathrm{~h}$. ${ }^{b}$ Determined by SEC analysis in THF using polystyrene standards. ${ }^{c} \mathrm{~N}$ chains $=M_{\mathrm{n}(\text { (exp) without cTA }} / M_{\mathrm{n}(\text { (exp) }}$ with CTA. ${ }^{d}$ calculated for $64 \%$ conversion of isoprene: $N$ chains $=\left[M_{n}(\exp )\right.$ without CTA $/ M_{n}(\exp )$ with CTA $] \times 0.64$

From these results, we could notice a unique trend in the decrease of $M_{n}$ values, which is consistent with the increasing quantities of CTA. By adding 5 eq. of $\mathrm{ZnEt}_{2} / 4$, the molar mass is reduced by a factor of 4.7 (entries 2 vs 1 , Table 2), which in turn is lowered by a factor of 7.6 (entries 3 vs 1, Table 2) as the amount of CTA gets doubled. This decreasing trend is regularly maintained throughout the series of experiments as we compare the $M_{n}$ value of each entry from 5 to 100 eq. of $\mathrm{ZnEt}_{2} / 4$. This can also be seen through SEC analysis with the characteristic Gaussian curves shifting to the left (lower masses) as the amount of CTA is increasing (Fig. 1 and also see Figs. S36-S43 for SEC traces, ESI+). Importantly, the selectivity of $\mathbf{4}$ remained constant in all cases by increasing the quantity of CTA (Figs. S44-S51 for NMR spectra, ESI+). Nevertheless, we can observe that the use of a large amount of $\mathrm{ZnEt}_{2}$ does not decrease the dispersities, which remains constant during the set of experiments ( $\theta=1.2-1.5)$. Furthermore, the situation here is far from ideal since, for the most efficient system with a ratio of $4 / \mathrm{ZnEt}_{2}=1 / 10$, less than 8 chains were formed whereas a number of 21 chains was expected $(20$

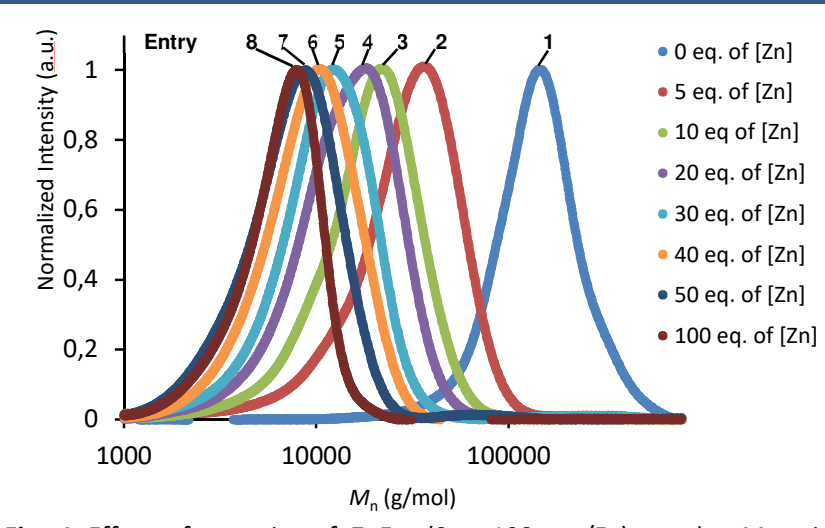

Fig. 1 Effect of quantity of $\mathrm{ZnEt}_{2}\left(0-100\right.$ eq./Fe) on the $M_{n}$ using 4/Al'Bu ${ }^{i} /\left[\mathrm{B}\left(\mathrm{C}_{6} \mathrm{~F}_{5}\right)_{4}\right]\left[\mathrm{CPh}_{3}\right]$ catalytic system (according to data in Table 2) 
chains from the two Et groups of $\mathrm{ZnEt}_{2}$ and 1 chain from catalyst activation with $\left.\mathrm{Al}^{i} \mathrm{Bu}_{3} /\left[\mathrm{B}\left(\mathrm{C}_{6} \mathrm{~F}_{5}\right)_{4}\right]\left[\mathrm{CPh}_{3}\right]\right)$. This result potentially indicates that at best only one of the two ethyl groups of $\mathrm{ZnEt}_{2}$ is transferred to the iron center to initiate a polymer chain growth, which could preclude the possibility of carrying two polymer chains per $\mathrm{Zn}$, highlighting some of the limitations of this system.

One of the remarkable extensions of CCTP concept is represented by Chain Shuttling Polymerization (CSP), where a dual-catalyst system in presence of CTA is used to generate distinct growing macromolecular chains, either from two comonomers or from a unique monomer that can lead to different chain regularities depending on the regio-, chemo- or stereo-selectivity of each catalyst. Thus, the two distinct growing chains are reversibly transferred from one catalyst to another by means of the CTA (here called the chain shuttling agent), giving rise to multiblock architectures that contain block segments with the microstructural signature of each catalyst. ${ }^{20}$ In this context, CSP of conjugated dienes has been independently described by three research groups using either two regio-21 or stereoselective ${ }^{22,23}$ rare-earth catalysts in the presence of CTA, producing poly(1,3-dienes) multiblock containing alternated 3,4-/1,4-polyisoprene block or cis/trans-block of either polyisoprene or polybutadiene, respectively. Despite the moderate regio- and stereo-selectivity of our iron-based systems for the CCTP of isoprene, we still attempted to prepare multiblock polyisoprene by CSP. For this purpose, we chose to use complexes $\mathbf{1}$ and $\mathbf{3}$

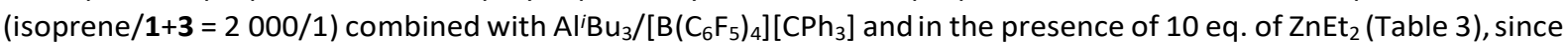
the transfer efficiencies are quite similar between these two catalysts ( $\mathrm{N}$ chains $=2.7-3$ for complex $\mathbf{1}$ and 3, Table 1 , entries 2 and 6 ) and also result in polymer chains with distinguishable stereo- and regio-regularities (trans-1,4/cis1,4/3,4 content $=33 / 46 / 21$ for complex 1 vs 69/22/9 for complex 3 ). Detailed studies of the CSP tests can be found in Table S3 and Figs. S52-S73 in ESIt.

Table 3 Attempt CSP of isoprene using 1+3/Al'Bu $3 /\left[\mathrm{B}\left(\mathrm{C}_{6} \mathrm{~F}_{5}\right)_{4}\right]\left[\mathrm{CPh}_{3}\right]$ catalytic system with and without $\mathrm{ZnEt}_{2}{ }^{\mathrm{a}}$

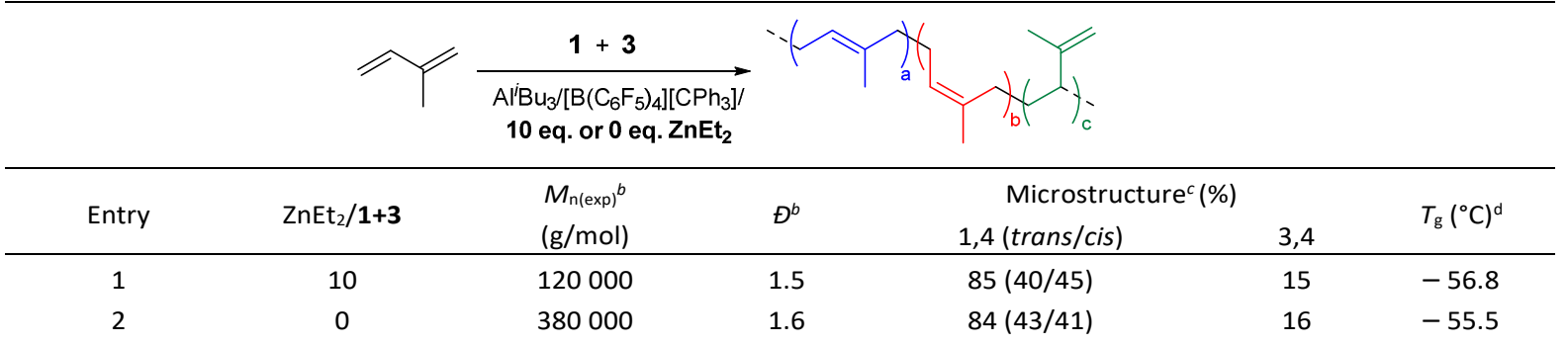

a Polymerization conditions: $10 \mu \mathrm{mol}$ of complex 1+3, isoprene $/ \mathbf{1}+\mathbf{3} / \mathrm{Al}^{i} \mathrm{Bu}_{3} /\left[\mathrm{B}\left(\mathrm{C}_{6} \mathrm{~F}_{5}\right)_{4}\right]\left[\mathrm{CPh}_{3}\right]=2000 / 1 / 3 / 1$, toluene $=20 \mathrm{~mL}$, $[\mathrm{C}]$ isoprene $=1 \mathrm{~mol} / \mathrm{L}$, temperature $=25^{\circ} \mathrm{C}$, time $=6 \mathrm{~h} .{ }^{b}$ Determined by SEC analysis in THF using polystyrene standards. ${ }^{c}$ Determined by ${ }^{1} \mathrm{H} \mathrm{NMR}$ and ${ }^{13} \mathrm{C}$ NMR. ${ }^{d}$ Determined by DSC.

The CSP attempt of isoprene using complexes 1 and 3 in a ratio of $1 / 1$ leads to a polyisoprene with $M_{\mathrm{n}}=$ $180000 \mathrm{~g} / \mathrm{mol}(\Theta=1.5)$ and a microstructure in which the content of trans-1,4/cis-1,4/3,4 = 40/45/15 reflects the average 1,4/3,4 selectivities of both catalysts (85/15, Table 3, entry 1 , between $79 / 21$ and $91 / 9$, entries 2 and 6 , Table 1 , respectively). Additionally, the determination of the $T_{\mathrm{g}}$ shows a value of $-56.8^{\circ} \mathrm{C}$, which is an intermediate value of the polymers produced independently by complexes 1 and 3 under CCTP conditions (between $-51.6^{\circ} \mathrm{C}$ and $-61.7^{\circ} \mathrm{C}$, entries 1 and 5 , Table S3, ESI resulted in a polyisoprene presenting a stereo-, regio-regularity along with a $T_{\mathrm{g}}$ value quasi similar to that obtained in the presence of CTA (Table 3, entry 2). The unique glass transition found at $-55.5^{\circ} \mathrm{C}$ was expected given that the physical mixture of the two homopolymers, produced independently by CCTP, displays a single $T_{\mathrm{g}}$ of $-57.1^{\circ} \mathrm{C}$ (Fig. S70) due to the miscibility of the blend. However, the resulting $M_{n}$ of the polymer produced under CSP was found to be 3 times lower than that achieved without $\mathrm{ZnEt}_{2}\left(M_{\mathrm{n}}=180000 \mathrm{vs} 380000 \mathrm{~g} / \mathrm{mol}\right.$, respectively), which is similar to the number of chains generated for each independent complex under CCTP (entries 5-6, Table 1). Moreover, the dispersity was 1.5 vs. 1.6 in absence of Zn-CTA. Thus, these results partially suggest the occurrence of a CSP process, however, the moderate selectivity of both iron complexes prevents us from asserting unequivocally that it has indeed taken place. Alternatively, we cannot totally exclude that the growing chains on each iron catalyst are not transferred from one to the other through the $\mathrm{Zn} \mathrm{CTA}$, thus producing a mixture of two homopolymers that distinctively incorporate the signature of each catalyst rather than a single polyisoprene chain displaying a multiblock structure.

In this study, we have successfully demonstrated the first CCTP of isoprene with an iron-based catalytic system. Various metal alkyls were screened as potential CTAs during the CCTP of isoprene, among which it was observed that the transfer is only efficient with $\mathrm{ZnEt}_{2}$, owing to an appropriate combination between the catalyst and the chain transfer agent. The ketiminopyridine iron complex $\mathbf{4}$ bearing sterically hindered $\mathrm{N}$-aryl substituents was the most efficient under CCTP conditions when compared to the less sterically crowded complex $\mathbf{3}$ and the aldiminopyridine iron complexes $\mathbf{1}$ and $\mathbf{2}$, although the transfer efficiency between $\mathbf{4}$ and $\mathrm{ZnEt}_{2}$ was not total (36\%, 
considering alkyls-CTA). Attempts of performing a polymerization of isoprene using a mixture of complexes $\mathbf{1}$ and $\mathbf{3}$ combined with 10 eq. $\mathrm{ZnEt}_{2}$, after cocatalyst activation, might suggest the occurrence of a CSP process.

Further development of iron-catalyzed reversible chain transfer coordinative polymerization, such as the preparation of block copolymers or the functionalization of polymer chain-end, is currently in progress and will be reported in due course.

\section{Acknowledgements}

We warmly thank the University of Lille for the financial support of O. H. Hashmi and the CNRS for partially funding this work. Aurélie Malfait and Dr. Jonathan Potier are acknowledged for SEC analyses. Dr. Eric Buisine and Patrick Daubias are gratefully thanked for their assistance with NMR spectroscopy.

\section{Notes and references}

1 (a) R. Kempe, Chem. Eur. J., 2007, 13, 2794; (b) L. R. Sita, Angew. Chem., Int. Ed., 2009, 48, 2464; (c) A. Valente, A. Mortreux, M. Visseaux and P. Zinck, Chem. Rev., 2013, 113, 3836.

2 (a) A. Valente, P. Zinck, M. J. Vitorino, A. Mortreux and M. Visseaux, J. Polym. Sci. Part A: Polym. Chem., 2010, 48, 4640; (b) L. Pan, K. Zhang, M. Nishiura and Z. Hou, Angew. Chem., Int. Ed., 2011, 50, 12012; (c) S. Georges, A. O. Touré, M. Visseaux and P. Zinck, Macromolecules, 2014, 47, 4538; (d) J. Jothieswaran, S. Fadlallah, F. Bonnet and M. Visseaux, Catalysts, 2017, 7, 378; (e) F. Wang, H. Liu, Y. Hu and X.-Q. Zhang, Sci. China Technol. Sci., 2018, 61, 1286; (f) Z. Tang, A. Liang, H. Liang, J. Zhao, L. Xu and J. Zhang, Macromol. Res., 2019, $27,789$.

3 W. Zheng, F. Wang, J. Bi, H. Zhang, C. Zhang, Y. Hu, C. Bai and X. Zhang, J. Polym. Sci. Part A: Polym. Chem., 2015, 53, 1182. The process is carried out under very specific conditions and cannot be generalized since the reversible transfer is no longer effective when the $\mathrm{Al} / \mathrm{Fe}$ ratio $>8$.

4 H. Liu, F. Wang, L. Liu, B. Dong, H. Zhang, C. Bai, Y. Hu and X. Zhang, Inorg. Chim. Acta, 2014, 421, 284. The rate of polymerization decreases upon addition of CTA but the interpretations are questionable as they do not consider that $M_{n}$ reduction is related to the lower conversion of butadiene when an increasing molar ratio of $\mathrm{Zn} / \mathrm{Co}$ is used.

5 See, for example C. Jing, L. Wang, G. Zhu, H. Hou, L. Zhou and Q. Wang, Organometallics, 2020, 39, 4019. The activation of the pre-catalyst by MAO can lead, in certain cases, to uncontrolled chain transfer of the poly-1,3-diene chains to Al due to the presence of free AlMe ${ }_{3}$.

6 (a) C. Bolm, J. Legros, J. Le Paih and L. Zani, Chem. Rev., 2004, 104, 6217; (b) E. B. Bauer, Top. Organomet. Chem., 2015, 50, 1; (c) E. B. Bauer and H.J. Knölker, Chem. Rev., 2015, 115, 3170; (d) A. Fürstner, ACS Cent. Sci., 2016, 2, 778; (e) J. R. Ludwig and C. S. Schindler, Chem., 2017, 2, 313; (f) A. Piontek, E. Bisz and M. Szostak, Angew. Chem., Int. Ed., 2018, 57, 11116; (g) D. Wei and C. Darcel, Chem. Rev., 2019, 119, 2550; (h) A. Guðmundsson and J.-E. Bäckvall, Molecules, 2020, 25, 1349; (h) P. G. N. Neate and M. L. Neidig, Nat. Rev. Chem., 2021, 1.

7 (a) B. Burcher, P.-A. R. Breuil, L. Magna and H. Olivier-Bourbigou, Top. Organomet. Chem., 2015, 50, 217; (b) Y. Champouret, O. H. Hashmi and M. Visseaux, Coord. Chem. Rev., 2019, 390, 127.

8 See for example these comprehensive reviews: (a) C. Bianchini, G. Giambastiani, I. G. Rios, G. Mantovani, A. Meli and A. M. Segarra, Coord. Chem. Rev., 2006, 250, 1391; (b) V. C. Gibson, C. Redshaw and G. A. Solan, Chem. Rev., 2007, 107, 1745; (c) J. Ma, C. Feng, S. Wang, K.-Q. Zhao, W.-H. Sun, C. Redshaw and G. A. Solan, Inorg. Chem. Front., 2014, 1, 14; (d) Z. Wang, G. A. Solan, W. Zhang and W.-H. Sun, Coord. Chem. Rev., 2018, 363, 92 and references therein.

9 (a) G. J. P. Britovsek, S. A. Cohen, V. C. Gibson, P. J. Maddox and M. van Meurs, Angew. Chem., Int. Ed., 2002, 41, 489; (b) G. J. P. Britovsek, S. A. Cohen, V. C. Gibson and M. van Meurs, J. Am. Chem. Soc., 2004, 126, 10701; (c) M. van Meurs, G. J. P. Britovsek, V .C. Gibson and S. A. Cohen, J. Am. Chem. Soc., 2005, 127, 9913.

10 G. Ricci, A. Sommazzi, F. Masi, M. Ricci, A. Boglia and G. Leone, Coord. Chem. Rev., 2010, $254,661$.

11 (a) L. Porri, A. Giarrusso and G. Ricci, Prog. Polym. Sci., 1991, 16, 405; (b) L. S. Baugh and J. A. M. Canich. Stereoselective Polymerization with SingleSite Catalysts; Taylor \& Francis: New York, 2008, 447.

12 O. H. Hashmi, Y. Champouret and M. Visseaux, Molecules, 2019, 24, 3024

13 (a) J. Raynaud, J. Y. Wu, T. Ritter, Angew. Chem., Int. Ed., 2012, 51, 11805; (b) L. Guo, X. Jing, S. Xiong, W. Liu, Y. Liu, Z. Liu and C. Chen, Polymers, 2016, 8, 389; (c) G. Zhu, X. Zhang, M. Zhao, L. Wang, C. Jing, P. Wang, X. Wang and Q. Wang, Polymers, 2018, 10, 934; (d) M. Zhao, L. Wang, Q. Mahmood, C. Jing, G. Zhu, X. Zhang, X. Wang and Q. Wang, Appl. Organomet. Chem., 2019, e4836; (e) W. Lin, L. Zhang, H. Suo, A. Vignesh, N. Yousuf, X. Hao and W.H. Sun, New J. Chem., 2020, 44, 8076; (f) L. Wang, X. Wang, H. Hou, G. Zhu, Z. Han, W. Yang, X. Chen and Q. Wang, Chem. Commun., $2020,56,8846$

14 (a) R. Cariou and J. W. Shabaker, ACS Catalysis, 2015, 5, 4363-4367; (b) M. Khoshsefat, A. Dechal, S. Ahmadjo, M. M. Mortazavi, G. H. Zohuri and J. B. P. Soares, Chem CatChem, 2020, 12, 5809.

15 S. S. Karpiniec, D. S. McGuinness, G. J. P. Britovsek, N. W. Davies and J. Patel, Catal. Today, 2011, 178, 64.

16 X.-B. Wang, M. Zhang, L. Luo, M. Hussain and Y. Luo, Chem. Phys. Lett., 2020, 755, 137811.

17 S. Kaita, M. Yamanaka, A. C. Horiuchi and Y. Wakatsuki, Macromolecules, 2006, 39, 1359.

18 One of the referees questioned whether the transfer was limited to $\mathrm{ZnEt}_{2}$ as CTA or if a sterically less hindered aluminum reagent, AlEt $\mathrm{C}_{3}$, could be used as CTA. We performed an experiment with isoprene/AlEt $3 /\left[\mathrm{B}\left(\mathrm{C}_{6} \mathrm{~F}_{5}\right)_{4}\right]\left[\mathrm{CPh}_{3}\right] / 4=500 / 10 / 1 / 1$ and found that the resulting $M_{\mathrm{n}}(20000 \mathrm{~g} / \mathrm{mol})$ was reduced by only a factor of 2 compared to the experiment conducted in the presence of isoprene/Ali $\mathrm{Bu}_{3} /\left[\mathrm{B}\left(\mathrm{C}_{6} \mathrm{~F}_{5}\right)_{4}\right]\left[\mathrm{CPh} \mathrm{C}_{3}\right] / 4=500 / 10 / 1 / 1(41000$ $\mathrm{g} / \mathrm{mol})$, thus emphasizing that, under these experimental conditions, Al reagents were not highly effective as CTA when compared to ZnEt ${ }_{2}$ where $M_{\mathrm{n}}$ is reduced by 7.6 .

19 J. Ducom, Bull. Soc. Chim. Fr., 1971, 10, 3529.

20 (a) D. J. Arriola, E. M. Carnahan, P. D. Hustad, R. L. Kuhlman and T. T. Wenzel, Science, 2006, 312, 714; (b) V. C. Gibson, Science, 2006, 312, 703; (c) M. Zintl and B. Rieger, Angew. Chem., Int. Ed., 2007, 46, 333.

21 B. Liu and D. Cui, Macromolecules, 2016, 49, 6226.

22 Y. Phuphuak, F. Bonnet, G. Stoclet, M. Bria and P. Zinck, Chem. Commun., 2017, 53, 5330

23 Q. Dai, X. Zhang, Y. Hu, J. He, C. Shi, Y. Li and C. Bai, Macromolecules, 2017, 60, 7887 